\title{
Radiation diarrhoea and cholestyramine
}

\author{
JOHN R. CONDON* \\ B.Sc., M.B., M.R.C.P. \\ MARIE SOUTH $\dagger$ \\ M.B., B.S., F.R.C.S.
RICHARD L. WOLVERSON*
M.B., B.S. \\ DiANA BRINKLEY \\ M.A., M.B., D.M.R.T., F.R.C.P. \\ Brook General Hospital,* St George's Hospital, $\uparrow$ and Kings College Hospital, London
}

\begin{abstract}
Summary
Radiation diarrhoea was treated successfully with cholestyramine, and this is confirmed by faecal biochemistry. The reasons for this response are discussed and it is suggested that the resin may affect gut bacterial activity.
\end{abstract}

\section{Introduction}

Acute radiation injury to the intestines may occur during radiotherapy and is characterized by diarrhoea and tenesmus. Symptoms were relieved by treatment with cholestyramine.

\section{Case report}

A 72-year-old woman was treated with radiotherapy for carcinoma of the bladder. She was given a course of telecobalt therapy, 30 fractions in $\mathbf{4 5}$ days. The total tumour dose was $6000 \mathrm{rad}$.

During the 4th week of radiotherapy her stools became watery and loose and by the 5th week she was having 18-20 watery stools/day. Treatment with kaolin and morphine, $10 \mathrm{ml} / 6 \mathrm{hr}, 2$ tablets $/ 6 \mathrm{hr}$ of diphenoxylate and atropine (Lomotil), and dihydrocodeine $60 \mathrm{mg} / 4 \mathrm{hr}$ reduced the number of stools to 9-10/day but faecal consistency was unchanged.

All treatment was stopped for $24 \mathrm{hr}$ and a 3-day collection of faeces was made. The patient was given cholestyramine $4 \mathrm{~g} / 6 \mathrm{hr}$ and $4 \mathrm{~g}$ at night. Over the next $24 \mathrm{hr}$ she had ten semi-solid stools and the following day there were four fairly well formed stools. Thereafter two to three formed stools/day were passed and a second 3-day collection of faeces was made.

Total faecal bile acids were normal at $311 \mathrm{mg} /$ $24 \mathrm{hr}$ - lithocholic acid was 103-105 mg and deoxycholic was $207.5 \mathrm{mg}$. No measurable quantities of chenodeoxycholic and cholic acids were found in the stools.

The number of motions and faecal biochemistry before and during cholestyramine therapy are compared in Table 1.
TABLE 1.

Daily stool frequency, water and electrolyte content before் and during treatment

\begin{tabular}{|c|c|c|}
\hline Measurements $/ 24 \mathrm{hr}$ & $\begin{array}{c}\text { No } \\
\text { treatment }\end{array}$ & Cholestyramine \\
\hline $\begin{array}{l}\text { Average number of stools } \\
\text { Weight of faeces (g) } \\
\text { Faecal fluid (g) } \\
\text { Dry weight (g) } \\
\text { Sodium (mmol) } \\
\text { Potassium (mmol) }\end{array}$ & $\begin{array}{r}18 \cdot 0 \\
178 \cdot 2 \\
163 \cdot 2 \\
14 \cdot 9 \\
5 \cdot 7 \\
6 \cdot 6\end{array}$ & 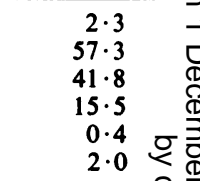 \\
\hline
\end{tabular}

The patient had an excellent clinical and bio요 chemical response to cholestyramine; stool water sodium and potassium levels falling despite the fach that faecal bile acids were within the normal range $\frac{}{\mathbb{P}}$

Because of a poor appetite, the patient had a smalP food intake as reflected by low dry weight of faeceso을 It is, therefore, possible that if the bile acids were expressed in terms of dry weight of faeces, their concentration in the gut lumen might be higher than that in a normal person, and thus account for the diarrhoea and its response to cholestyramine.

Patients with diarrhoea as a result of radiotherapy for pelvic malignancy have abnormal boweक radiology and positive cholyl-glycine-1-14 $\mathrm{C}$ breath tests (Newman et al., 1973). Based on the conversion of glycine-1-14 $\mathrm{C}$ to $\mathrm{CO}_{2}$ by bacterial and tissue enzymes, the test is positive in bacterial overgrowth syndromes and when the entero-hepatic circulation is:interrupted by ileal damage or disease (Hofmann et al., 1970; James et al., 1972; Condon et al. 1974).

It should, however, be noted that, unlike patients with ileal resections (Mitchell and Eastwood, 1972) no measurable quantities of chenodeoxycholic an cholic acids were found in the faeces of the patien and this suggests bacterial activity of organisms known to break down primary to secondary biles 
acids. Since dilatation of the ileum and failure of the terminal ileal loop to retain barium has been reported, it is conceivable that post-radiation diarrhoea might be related to bacterial invasion of the ileum as a consequence of radiation damage to the ileo-caecal valve. The normal total faecal bile acids of the patient would tend to support this concept rather than malabsorption by the terminal ileum, in which case one would expect stool bile acids to be unequivocally elevated.

One must, however, account for the dramatic response to cholestyramine and it is known that the compound may affect bacterial activity in a number of ways. Firstly, the resin is capable of binding endotoxin (Nolan and Ali, 1972), and there is evidence that endotoxins can cause diarrhoea Gorbach, 1970; Gorbach and Khurana, 1972). Furthermore, the bacterial flora of the gut might also be modified by cholestyramine. The reasons for this are twofold. Certain organisms such as Bacteroides fragilis are stimulated by bile acids and the activity of such bacteria may be decreased by the unavailability of bile acids bound to the resin. Secondly, certain bile acids exert a pronounced bactericidal effect at pH 5.6 and this decreases as the pH rises to 7.2 (Percy-Robb and Collee, 1972).

The authors have controlled radiation diarrhoea in two other patients and the resin has been reported as preventing symptoms in some animals with radiation-induced enteritis (Berk and Seay, 1972). The compound may, therefore, be a useful drug for controlling this debilitating disorder in man.

\section{Acknowledgment}

We thank Dr B. J. Freedman for his co-operation.

\section{References}

BERK, R.N. \& SEAY, D.G. (1972) Cholerheic enteropathy as a cause of diarrhoea and death in radiation enteritis and its prevention with cholestyramine. Radiology, 104, 153.

Condon, J.R., Suleman, M.I., Fan, Y.S. \& McKeown, M.D. (1974) Cholestyramine and diabetic and postvagotomy diarrhoea. British Medical Journal, 1, 519.

GoRBACH, S.L. (1970) Acute diarrhea - a 'toxin' disease? New England Journal of Medicine, 283, 44.

Gorbach, S.L. \& Khurana, O.M. (1972) Toxigenic Escherichia coli. New England Journal of Medicine, 287, 791.

HofmanN, A.F., Thomas, P.J., Smith, L.H. \& McCall, J.T. (1970) Pathogenesis of secondary hyperoxaluria in patients with ileal resection and diarrhoea. Gastroenterology, 58, 960.

James, O., Agnew, J.E., Lydford, R. \& Bouchier, A.D. (1972) An evaluation of a breath test to detect altered bile acid metabolism. Gut, 13, 845.

Mitchell, W.D. \& EASTwood, M.A. (1972) Faecal bile acids and neutral steroids in patients with ileal dysfunction. Scandinavian Journal of Gastroenterology, 7, 29.

Newman, A., Katsaris, J., Blendis, L.M., Charlesworth, M. \& WATER, L.H. (1973) Small intestinal injury to women who have had pelvic radiotherapy. Lancet, ii, 1471.

NolAN, J.P. \& ALI, M.V. (1972) Effect of cholestyramine on endotoxin toxicity and absorption. American Journal of Digestive Diseases, 17, 161.

Percy-Robb, I.W. \& Collee, J.G. (1972) Bile acids: a pH dependent antibacterial system in the gut? British Medical Journal, 3, 813. 